\title{
Bipteria formosa (Kovaleva et Gaevskaya, 1979) comb. n. (Myxozoa: Myxosporea) in whiting Merlangius merlangus (Teleostei: Gadidae) from Denmark
}

\author{
Egil Karlsbakk $^{1}$ and Marianne Køie ${ }^{2}$ \\ ${ }^{1}$ Institute of Marine Research, Postboks 1870 Nordnes, N-5817 Bergen, Norway; \\ ${ }^{2}$ Marine Biological Laboratory, University of Copenhagen, DK-3000 Helsingør, Denmark
}

\begin{abstract}
A total of 22 specimens of whiting Merlangius merlangus (L.) (Teleostei, Gadidae) from the northern Øresund, Denmark were examined for Myxosporea. Zschokkella hildae Auerbach, 1910 (Myxidiidae), Gadimyxa sp. (Parvicapsulidae) and a species of Bipteria occurred in the renal tubules of $9 \%, 18 \%$ and $68 \%$ whiting, respectively. Immature spores of the Bipteria species are very similar to spores of Myxoproteus formosus Kovaleva et Gaevskaya, 1979 originally described from the urinary system of whiting from the Celtic Sea. We therefore consider Bipteria sp. from whiting in Denmark conspecific with M. formosus and propose Bipteria formosa (Kovaleva et Gaevskaya, 1979) comb. n. The spore of Bipteria formosa is described in detail and compared with other Bipteria spp. The phylogenetic position of B. formosa, based on partial 18S rDNA sequences, is closest to Leptotheca fugu Tun, Yokoyama, Ogawa et Wakabayashi, 2000 and the Sphaerosporidae.
\end{abstract}

Key words: Myxozoa, Bipteria formosa, Myxoproteus formosus, Zschokkella hildae, Gadimyxa, Merlangius merlangus, $18 \mathrm{~S}$ rDNA sequences, Denmark

The whiting Merlangius merlangus (L.) has frequently been examined for myxozoans, and 13 species have been recorded. However, only two studies on parasites of whiting from the Celtic Sea record myxosporeans in the urinary system, Myxoproteus formosus Kovaleva et Gaevskaya, 1979 and Zschokkella hildae Auerbach, 1910 (Kovaleva and Gaevskaya 1979, Gaevskaya and Kovaleva 1984).

During a survey of the myxozoan fauna in Danish marine fish, three species were found in the renal tubules of M. merlangus from the northern Øresund, Denmark. Zschokkella hildae has been recorded in whiting previously, whereas Gadimyxa sp. (Parvicapsulidae) infections have not previously been reported from this host. The third species, a member of the genus Bipteria Kovaleva, Zubchenko et Krasin, 1983, represents a new form, described herein but identified with Myxoproteus formosus Kovaleva et Gaevskaya, 1979, a species that appears to have been described on the basis of immature spores. The objective of the present study is to redescribe Bipteria formosa comb. n. and report its phylogenetic affinities as indicated by partial $18 \mathrm{~S}$ rDNA sequences.

\section{MATERIALS AND METHODS}

In all, 22 specimens of Merlangius merlangus, 21-37 cm long, were bottom-trawled in the Øresund at 16-20 m, in Sep- tember and November 2007. The fish were frozen immediately upon capture. Smears were made of bile and gallbladder, urine, urinary bladder wall and various parts of the kidney. Measurements ( $\mathrm{n}=15$ fish, 10 measurements of each parameter given as the range with the mean in parentheses) were taken immediately after samples were defrosted. Kidney pieces from infected M. merlangus were fixed in absolute ethanol for DNA analyses. Samples of Zschokkella hildae from urinary bladders of three Gadus morhua L. and a Phycis blennoides (Brünnich) from Norway were included to control for the occurrence of this parasite in whiting when running PCRs.

DNA extraction and PCR was done as described previously (Køie et al. 2008). Gadimyxa sp. sequences were obtained using the forward/reverse primer combinations MyxF2/Myxgen4R and MarF1/RosR2 with annealing at $58{ }^{\circ} \mathrm{C}$ (see Køie et al. 2007, 2008). Bipteria formosa sequences were obtained with the primer combinations Erib1/MybiR $\left(58^{\circ} \mathrm{C}\right.$ ) (see Køie et al. 2008) and BiptF1/18g $\left(55^{\circ} \mathrm{C}\right)$. The new forward primer BiptF1 has sequence 5'-TCA ACT TGA GTG GTG GTG ATC A. The PCR products were purified with E.Z.N.A. cycle-pure kit (Omega) and then sequenced using the BigDye (3.1) Terminator Sequencing kit, using the amplification primers described above. Sequence data were assembled with the Vector NTI Advance $^{\mathrm{TM}} 10.3$ software (Invitrogen Corp., Carlsbad, CA) and GenBank searches were done with Blast (2.0). Alignments were done with AlignX (Vector NTI). The phylogenetic affinities of the Bipteria species were examined with an alignment of the most similar Myxosporea sequences from Blast searches and 
selected members of more distantly related clades. Alignments were manually edited in GeneDoc (available at www.nrbsc.org/ gfx/genedoc) and hypervariable or ambiguous regions deleted to achieve comparison of homologous positions. Phylogenetic analysis of the data sets were performed with Paup* (4.0b10) (Maximum Likelihood, ML, largest dataset with 56 taxa was not bootstrapped), TreePuzzle (5.0) (ML, quartet puzzling algorithm=QP, 25,000 replicates) and MrBayes (3.1.2) (Bayesian inference) $\left(1.3 \times 10^{7}\right.$ generations $)$. General time reversible gamma + pinvar $(\mathrm{GTR}+\Gamma+\mathrm{I})$ models of nucleotide substitution was the best model for both datasets tested, according to ModelTest v. 3.1 (Posada and Crandall 1998). Phylogenetic trees were drawn using TreeView.

\section{RESULTS}

By microscopy, Gadimyxa sp. infections were found in the renal tubules of 4 of $22(18 \%)$ whiting. Gadimyxa sp. infections were detected in 6 of 7 fish examined by PCR and partial 18S rDNA sequencing. Four sequences were deposited in GenBank (FJ830376-9). A few isolated spores of the common gadoid myxozoan Zschokkella hildae Auerbach, 1910 were found in the renal tubules of 2 of 22 (9\%) whiting. Myxoproteus formosus Kovaleva et Gaevskaya, 1979 was found in the renal tubules of 15 of $22(68 \%)$ whiting. These myxospores were found in the renal tubules only, none was found in the urinary bladder. In addition to these myxozoans of the urinary system, spores of Myxidium sp. aff. gadi were found in the gallbladder of 16 of 22 (73\%) whiting. Spores of Myxobolus aeglefini Auerbach, 1906 were occasionally found in the examined kidney pieces.

Bipteria formosa (Kovaleva et Gaevskaya, 1979) comb. n. Figs. 1, 2 Syn.: Myxoproteus formosus Kovaleva et Gaevskaya, 1979

Type and only known host: Whiting Merlangius merlangus (L.) (Gadidae).

Type locality: Celtic Sea (south of Ireland).

Additional locality: Northern Øresund, between Helsingør and the island of Ven, Denmark $\left(55^{\circ} 58^{\prime} \mathrm{N}, 12^{\circ} 40^{\prime} \mathrm{E}\right)$, at $16-20 \mathrm{~m}$ depth.

Site of infection: Renal tubules.

Prevalence : 2 fish infected/9 fish examined (Kovaleva and Gaevskaya 1979), 15 fish infected/22 fish examined (68\%) (present study).

No external signs of infection were observed and most renal tubules were without any sign of infection. Myxospores were not found in the urinary bladder. Masses of myxospores were found in dilated sections of the renal tubules. The tubular epithelium in the sections was often atrophied and flattened (Fig. 1A). Granulomas measuring about $100 \mu \mathrm{m}$ in diameter were found between renal tubules, containing a high concentration of more or less atrophied myxospores. Occasionally, the lumen of the renal tubules contained irregular plasmodia c. $10 \mu \mathrm{m}$ in diameter with granular contents. Most plasmodia were without any sign of spores, but some contained two immature spores.

In sutural view, the body of the spore is nearly triangular, broadest anteriorly where the two spherical polar capsules occur. Thickness of the mature spore including valve extensions ('pockets') is $10.4-11.7 \mu \mathrm{m}(11.0 \mu \mathrm{m})$. Thickness of the spore just posterior to the thickening due to the pocket-like extensions is $8.1-9.0 \mu \mathrm{m}(8.5 \mu \mathrm{m})$. The length of the spore is $6.3-7.0 \mu \mathrm{m}(6.6 \mu \mathrm{m})$. The spore is elliptical in apical view (Figs. 1D, 2B), and subspherical in frontal or valvular view (Fig. 1F). Width of spore body is $6.3-7.0 \mu \mathrm{m}(6.6 \mu \mathrm{m})$. The spherical polar capsules, 3.4$3.8 \mu \mathrm{m}(3.6 \mu \mathrm{m})$ in diameter, are close to each other in mature spores; the smaller polar capsules of younger spores are more apart. Extruded filaments are $45 \mu \mathrm{m}$ in length. The straight, protruding sutural line divides the spore into two identical valves, and appears as sutural notches on the spore surface. A single binucleate sporoplasm was observed (Fig. 1B). An empty-looking closed pocket occurs at each side of immature spores (Fig. 1B, D). The pocket detaches posteriorly in more developed spores (Fig. 1C), leaving pointed notches at the previous areas of attachment. In fully mature spores (Figs. 1B, E-G, 2A) the pocket has opened and the content has been released. The wing-like extensions due to the valve-pockets of fully developed spores do not reach the posterior end of the spore (Figs. 1B, E-G, 2A). The released content of the valve pockets was observed to be swelling, resulting in an apparent mucous envelope that surrounds the posterior part of the spore (Fig. 1F). The width of the valve-pockets is slightly smaller than the width of the spore body.

PCR with different primer combinations for myxosporean 18S rDNA on kidney samples from 7 Bipteriainfected whiting resulted in 6 Gadimyxa sp. sequences and 7 identical or nearly identical novel sequences, with Leptotheca fugu Tun, Yokoyama, Ogawa et Wakabayashi, 2000 (AB195805) as the closest hit in Blast-searches. Zschokkella hildae samples from Gadus morhua and Phycis blennoides did not yield PCR products with the primers used to amplify B. formosa. Therefore, the novel sequences with affinity to $L$. fugu were identified as those of B. formosa.

Three of the Bipteria sequences were extended to 2050 nt (isolates Bi-II, Bi-IV, Bi-VI; GenBank accession Nos. FJ790307, FJ790308, FJ790309 respectively). These partial $18 \mathrm{~S}$ rDNA sequences differed by 1 substitution in Bi-II compared to Bi-IV and BI-VI which were identical. In addition, 2 positions in Bi-II were ambiguous $(\mathrm{C} / \mathrm{T}$ double signals). Four other partial sequences (Bi-I, Bi-III, Bi-V, Bi-VII) of 1144-1743 nt did not reveal additional variation and were identical to $\mathrm{Bi}-\mathrm{IV} / \mathrm{Bi}-\mathrm{VI}$.

Phylogenetic analyses were performed on the basis of two datasets, respectively with 24 species/1203 characters 

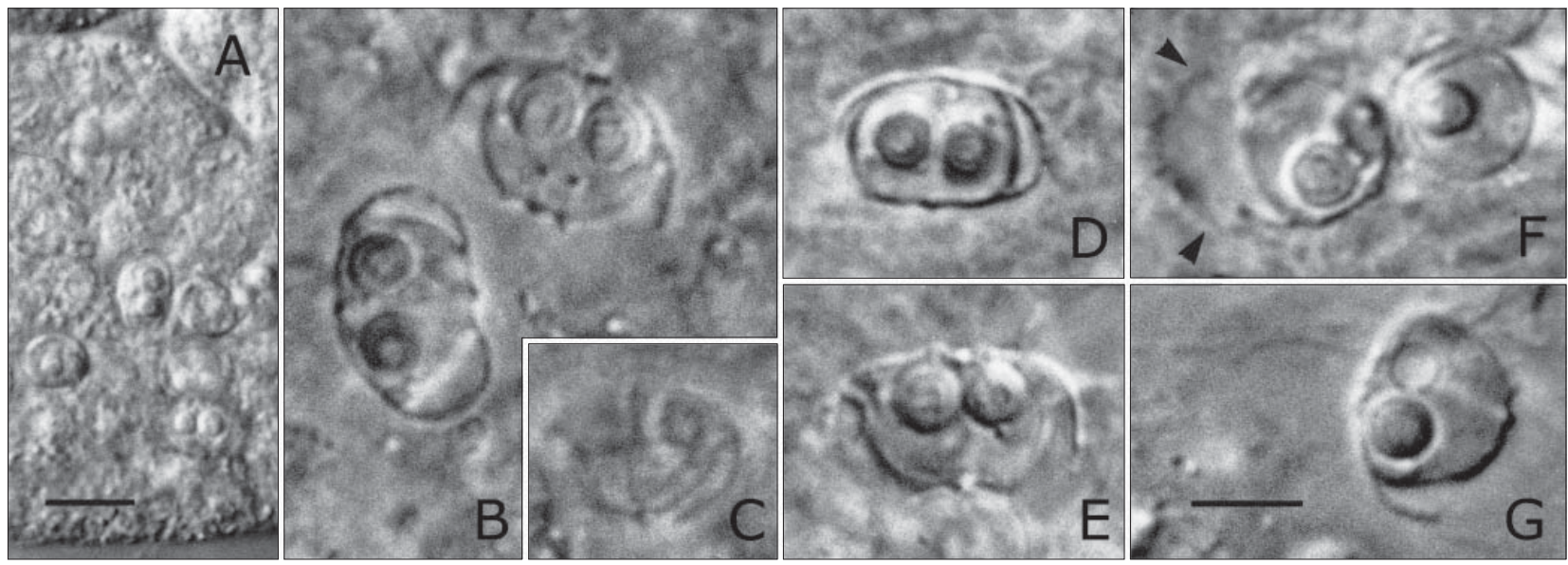

Fig. 1. Bipteria formosa (Kovaleva et Gaevskaya, 1979) comb. n. from Merlangius merlangus; interference contrast. A - Dilated section of renal tubule with mature spores. Note atrophied tubular epithelium. B - Two spores in sutural view; that to the left with closed valve pockets, the other fully mature. C - Sutural view of not fully developed spore focused on sutural line. The valve pockets have opened at basal end of spore. D - Apical view of nearly fully developed spore. E - Sutural view of mature spore with open valve pockets. $\mathbf{F}$ - The spore to the left is shown in oblique sutural view. A mucous envelope encloses the posterior part of the spore (arrowheads). The spore to the right is shown in frontal or valvular view. $\mathbf{G}-$ Sutural view of spore with one extruded filament. Scale bars: $\mathrm{A}=10 \mu \mathrm{m} ; \mathrm{B}-\mathrm{G}=5 \mu \mathrm{m}$.
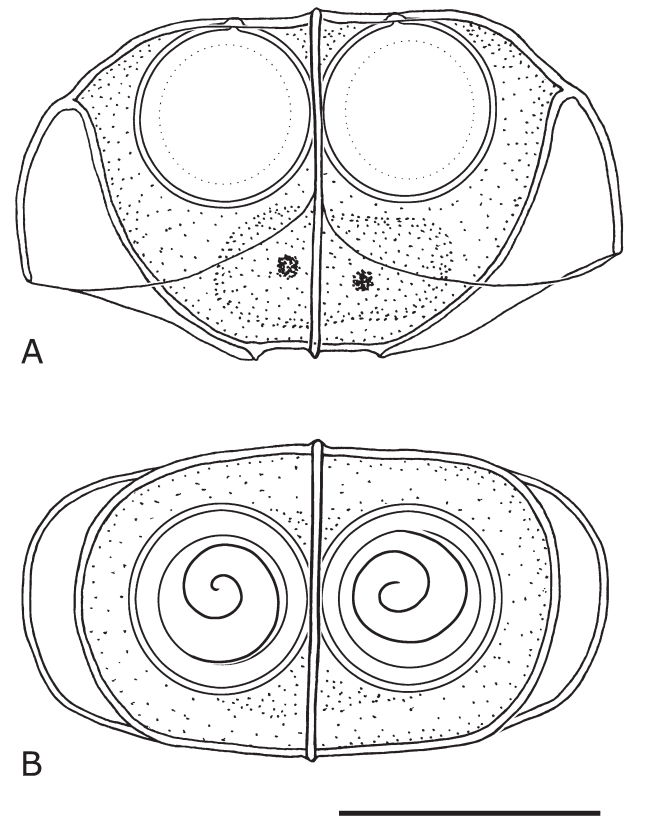

Fig. 2. Myxospores of Bipteria formosa (Kovaleva et Gaevskaya, 1979) comb. n. from the renal tubules of Merlangius merlangus. A - Sutural view. The number of coils of the polar filament in the polar capsules could not be ascertained, but the spatial extent of the coils is indicated. B - Apical view. Scale bar $=5 \mu \mathrm{m}$.

using ML (Paup \& QP) and 56 species/917characters using ML and Bayesian inference (QP \& MrBayes). Bipteria formosa grouped with Leptotheca fugu in all analyses, in a well supported clade together with Sphaerospora truttae Fischer-Scherl, El-Matbouli et Hoffmann, 1986. All analyses produced support for a sister group relationship between the Sphaerospora/Bipteria clade and the 'marine clade' (cf. Fiala 2006) of Myxosporea. All ML analyses placed Chloromyxum spp. from elasmobranchs as a sister group to the other Myxosporea (70-80\% support).

\section{DISCUSSION}

The gallbladder of whiting Merlangius merlangus has repeatedly been examined for myxozoans, and 10 species have been recorded. Despite numerous studies on whiting myxosporea in the Black Sea and northeast Atlantic, only Kovaleva and Gaevskaya (1979) and Gaevskaya and Kovaleva (1984) reported myxosporean infections in the urinary system. Gaevskaya and Kovaleva (1984) found Zschokkella hildae to be common in the urinary bladder of whiting from the Celtic Sea. In the present study, spores of this myxosporean were only seen in the renal tubules.

The Gadimyxa sp. infections detected in the present study were not studied in detail, but all sequences obtained were similar to those of Gadimyxa sp. from cod (Køie et al. 2007). In that study, the Gadimyxa sp. sequences were assumed to represent Gadimyxa sphaerica Køie, Karlsbakk et Nylund, 2007. Clearly, cod and whiting both host the same Gadimyxa species.

Myxoproteus formosus Kovaleva et Gaevskaya, 1979 was found in two of nine M. merlangus from the Celtic Sea (south of Ireland) (Kovaleva and Gaevskaya 1979). The thickness including "wings" of the myxospore in their material was $10.6-12.0 \mu \mathrm{m}$, the myxospore length was $9.3-10.4 \mu \mathrm{m}$. The spherical polar capsule measured $2.3 \mu \mathrm{m}$ in diameter. From our studies, it appears very likely that the described spores of $M$. formosus were not fully developed. Spores with similar measurements were found among immature spores in the present material. 


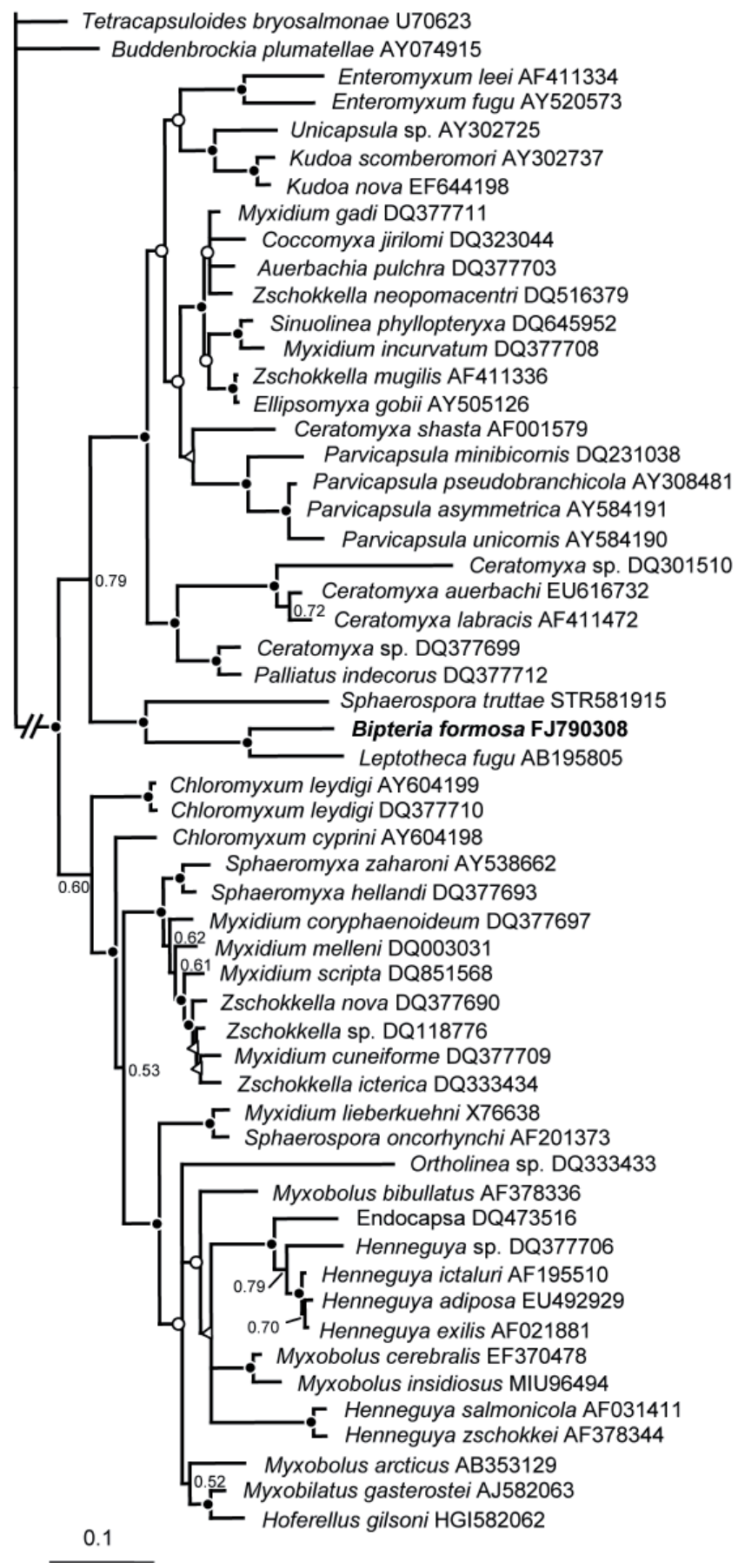

Fig. 3. Phylogenetic position of Bipteria formosa, as suggested by Bayesian inference of phylogeny (MrBayes 3.1). Based on an alignment of partial 18S rDNA sequences from 56 taxa with 917 characters. Support values at nodes: MrBayes posterior probabilities $<0.80$. Higher probabilities indicated by symbols at nodes: open triangles $0.80<0.90$, open circles $90<100$, closed circles $=100$. Only values above 0.50 indicated. Bar: 0.1 substitutions/site.
Fully developed spores in the present material have characters of the genus Bipteria and M. formosus is therefore assigned to the genus Bipteria Kovaleva, Zubchenko et Krasin, 1983. The genus Bipteria was erected for Bipteria admiranda, a parasite from the urinary bladder of Pagellus acarne (Risso) (Sparidae) from off Western Sahara (Kovaleva et al. 1983). Bipteria formosa differs from all six previously described species within this genus (Table 1). Bipteria merluccii and B. indica were found in the gallbladder, the remaining species were found in the urinary system. Bipteria admiranda and B. minima have relatively longer wings than $B$. formosa. Kpatcha et al. (1996) found B. admiranda in another sparid fish from off Senegal, West Africa. All other species of Bipteria have apparently only been recorded once. Bipteria magna and the only species found in a gadoid fish, B. merluc$c i i$, are both much larger than $B$. formosa and have relatively longer wings. In apical view, $B$. nototheniae has four pointed extensions. Bipteria indica has closed 'wing pockets', described as wing-like appendices.

Interestingly, the closest relative of $B$. formosa among the species for which $18 \mathrm{~S}$ rDNA sequences are available is Leptotheca fugu, a parasite of the intestinal epithelium of a marine fish in Japan. The spores of $L$. fugu show swellings of the valves much like those producing the pockets in spores of B. formosa (see Tun et al. 2000).

According to Kovaleva et al. (1983), Bipteria is close to the genus Myxoproteus. It differs from the latter by the presence of two wing-like appendices. The genus Bipteria is, together with among others Myxoproteus, usually placed in the Sinuolineidae (Lom and Dyková 2006). However, molecular data show that $B$. formosa is related to Leptotheca fugu and the Sphaerosporidae. The interrelationships between many myxosporean genera such as Sinuolinea, Leptotheca, Bipteria and Myxoproteus that are relevant here are unclear, since sequence information from the type species of these genera is not available. We consider it very likely that the Bipteria branch of the sphaerosporid clade will be much expanded by Bipteria spp. and related forms, and as our phylogenetic analyses exemplify, a more representative sampling of the Myxosporea may influence our comprehension of the phylogeny of the group. We therefore stress the need for sequence information from the many myxosporean species that infect the urinary system, which thus far are much underrepresented in phylogenetic studies of the Myxozoa.

Acknowledgement. We are grateful to A.C. Bårdsgjerde Einen of the Institute of Marine Research in Bergen for help with some PCR work. 
Table 1. Records of Bipteria spp. in marine fish. UB - urinary bladder; KT - kidney tubules; GB - gallbladder. Measurements in $\mu \mathrm{m}$. 1 - length; $\mathrm{w}$ - width; $\mathrm{t}$ - thickness; $\mathrm{mt}$ - thickness including wings.

\begin{tabular}{|c|c|c|c|c|c|c|c|c|}
\hline Species & Host & Site & Locality & Plasmodium & Myxospore & $\begin{array}{c}\text { Polar } \\
\text { capsule }\end{array}$ & $\begin{array}{l}\text { Myxospore } \\
\text { sutural view }\end{array}$ & Reference \\
\hline $\begin{array}{l}\text { B. admiranda Kovaleva, } \\
\text { Zubchenko et Krasin, } 1983\end{array}$ & $\begin{array}{l}\text { Pagellus acarne } \\
\text { Sparidae }\end{array}$ & UB & $\begin{array}{l}\text { East-central } \\
\text { Atlantic }\end{array}$ & $\begin{array}{l}\text { disporic to } \\
\text { polysporic }\end{array}$ & $\begin{array}{l}\text { 1 } 11-14 ; \\
\text { t } 11-12 ; \\
1 \text { wings } 13\end{array}$ & 4 & & $\begin{array}{l}\text { Kovaleva } \\
\text { et al. } 1983\end{array}$ \\
\hline $\begin{array}{l}\text { B. minima Kovaleva, } \\
\text { Zubchenko et Krasin, } 1983\end{array}$ & $\begin{array}{l}\text { Coryphaenoides } \\
\text { pectoralis } \\
\text { Macrouridae }\end{array}$ & UB & $\begin{array}{l}\text { Sea of } \\
\text { Okhotsk }\end{array}$ & $?$ & $\begin{array}{l}\text { 1 } 10-13 \\
\text { t } 11-13 \\
\text { mt } 17 \\
\text { w } 11\end{array}$ & $4-5$ & & $\begin{array}{l}\text { Kovaleva } \\
\text { et al. } 1983\end{array}$ \\
\hline $\begin{array}{l}\text { B. magna Kovaleva, } \\
\text { Zubchenko et Krasin, } 1983\end{array}$ & $\begin{array}{l}\text { C. pectoralis } \\
\text { Macrouridae }\end{array}$ & UB & $\begin{array}{l}\text { Sea of } \\
\text { Okhotsk }\end{array}$ & $?$ & $\begin{array}{l}116-19 \\
\text { t } 13-16 \\
\text { mt } 21-27\end{array}$ & 7 & & $\begin{array}{l}\text { Kovaleva } \\
\text { et al. } 1983\end{array}$ \\
\hline $\begin{array}{l}\text { B. nototheniae Koval- } \\
\text { eva et Rodyuk, } 1991\end{array}$ & $\begin{array}{l}\text { Patagonotothen ramsayi } \\
\text { Nototheniidae }\end{array}$ & $\mathrm{KT}$ & $\begin{array}{l}\text { South-west } \\
\text { Atlantic }\end{array}$ & $?$ & $\begin{array}{l}111-12 \\
\text { t } 11-15\end{array}$ & $4.2-4.7$ & & $\begin{array}{l}\text { Kovaleva and } \\
\text { Rodyuk } 1991\end{array}$ \\
\hline $\begin{array}{l}\text { B. merluccii Kovaleva, } \\
\text { Velev et Vladev, } 1993\end{array}$ & $\begin{array}{l}\text { Merluccius polli } \\
\text { Gadidae }\end{array}$ & GB & $\begin{array}{l}\text { Guinea } \\
\text { Bissau }\end{array}$ & disporic & $\begin{array}{l}110-11 ; \\
\text { mt 19-24 }\end{array}$ & $4.0-4.7$ & & $\begin{array}{l}\text { Kovaleva } \\
\text { et al. } 1993\end{array}$ \\
\hline $\begin{array}{l}\text { B. indica Kalavati et } \\
\text { Anuradha, } 1995\end{array}$ & $\begin{array}{l}\text { Mugil cephalus } \\
\text { Mugilidae }\end{array}$ & GB & India & disporic & $\begin{array}{l}15.8 \\
\text { t } 5.7 \\
\text { w } 5.0\end{array}$ & 2 & & $\begin{array}{l}\text { Kalavati and } \\
\text { Anuradha } \\
1995\end{array}$ \\
\hline $\begin{array}{l}\text { Myxoproteus formosus } \\
\text { Kovaleva et Gaevskaya, } 1979\end{array}$ & $\begin{array}{l}\text { Merlangius merlangus } \\
\text { Gadidae }\end{array}$ & UB & Celtic Sea & $?$ & $\begin{array}{l}\text { 1 } 9.3-10.4 \\
\text { t } 10.6-12.0\end{array}$ & 2.3 & & $\begin{array}{l}\text { Kovaleva and } \\
\text { Gaevskaya } \\
1979\end{array}$ \\
\hline $\begin{array}{l}\text { B. formosa (Kovaleva } \\
\text { et Gaevskaya, 1979) } \\
\text { Syn.: Myxoproteus formosus }\end{array}$ & $\begin{array}{l}\text { Merlangius merlangus } \\
\text { Gadidae }\end{array}$ & KT & $\begin{array}{l}\text { Northern } \\
\text { Øresund, } \\
\text { Denmark }\end{array}$ & disporic & $\begin{array}{l}16.6 \\
\text { t } 8.5 \\
\text { mt } 11.0 \\
\text { w } 6.6\end{array}$ & 3.6 & & Present study \\
\hline
\end{tabular}

\section{REFERENCES}

Fiala I. 2006: The phylogeny of Myxosporea (Myxozoa) based on small subunit ribosomal RNA gene analysis. Int. J. Parasitol. 36: $1521-1534$.

Gaevskaya A.V., Kovaleva A.A. 1984: [Materials on the myxosporidian fauna of the Celtic Sea fishes.] Vestn. Zool. (5): 3-7. (In Russian.)

Kalavati C., Anuradha I. 1995: A new myxosporean, Bipteria indica sp. n. (Myxosporea: Sinuolineidae) from the gall bladder of the striped mullet, Mugil cephalus Linnaeus. Acta Protozool. 34: 307-309.

Køie M., Karlsbakk E., Nylund A. 2007: A new genus Gadimyxa with three new species (Myxozoa, Parvicapsulidae) parasitic in marine fish (Gadidae) and the two-host life cycle of Gadimyxa atlantica n. sp. J. Parasitol. 93: 1459-1467.

Køie, M., Karlsbakk E., Nylund A. 2008: The marine herring myxozoan Ceratomyxa auerbachi (Myxozoa: Ceratomyxidae) uses Chone infundibuliformis (Annelida: Polychaeta: Sabellidae) as invertebrate host. Folia Parasitol. 55: 100-104.

Kovaleva A.A., Gaevskaya A.V. 1979: [Two new species of Myxosporidia of the genus Myxoproteus from Celtic Sea fishes.] Parazitologiya 13: 437-439. (In Russian.)

Kovaleva A.A., Rodyuk G.N. 1991: [New members of Myxosporidia (Cnidospora, Myxosporea) from fishes in the FalklandPatagonian region]. Parazitologiya 25: 549-551. (In Russian.)
Kovaleva A.A., Velev P., Vladev R. 1993: [New data on the myxosporean fauna (Cnidospora, Myxosporea) of commercial fishes from the Atlantic coast of Africa.] Sb. Nauchn. Tr. AtlantNIRO 1993: 174-194. (In Russian.)

Kovaleva A.A., Zubchenko A.V., Krasin V.K. 1983: [Foundation of a new myxosporean family (Protozoa, Myxosporidia) with a description of two new genera.] Parazitologiya 17: 195202. (In Russian.)

Kpatcha T.K., Diebakate C., Toguebaye B.S. 1996: Myxosporidies (Myxozoa, Myxosporea) des genres Sphaeromyxa Thélohan, 1892, Myxidium Bütschli, 1881, Zschokkella Auerbach, 1910, Bipteria Kovaljova, Zubtchenko \& Krasin, 1983 et Leptotheca Thélohan, 1895 parasites des poisons des côtes sénégalaises (Afrique de l'Ouest). J. Afr. Zool. 110: 309-317.

Loм J., DүкоvÁ I. 2006: Myхоzoan genera: definition and notes on taxonomy, life-cycle terminology and pathogenic species. Folia Parasitol. 53: 1-36.

Posada D., Crandall K.A. 1998: MODELTEST: testing the model of DNA substitution. Bioinformatics 14: 817-818.

Tun T., Yokoyama H., Ogawa K., Wakabayashi H. 2000: Myxosporeans and their hyperparasitic microsporeans in the intestine of emaciated tiger puffer. Fish Pathol. 35: 145-156. 